See discussions, stats, and author profiles for this publication at: https://www.researchgate.net/publication/290790169

\title{
Geology and Geomorphology of the Pantanal Basin
}

Chapter · January 2016

DOI: 10.1007/698_2015_349

\section{CITATIONS}

20

6 authors, including:

Mario Assine

São Paulo State University

154 PUBLICATIONS 1,923 CITATIONS

SEE PROFILE

Fabiano Pupim

Universidade Federal de São Paulo

32 PUBLICATIONS 144 CITATIONS

SEE PROFILE
Eder Renato Merino

University of São Paulo

17 PUBLICATIONS 64 CITATIONS

SEE PROFILE

-7. Lucas Veríssimo Warren

São Paulo State University

78 PUBlications 486 CITATIONS

SEE PROFILE

Some of the authors of this publication are also working on these related projects:

Hudson's Doctor Degree Thesis View project

Multi-proxy analysis of the Cerro Negro Formation, Argentina: bioestratigraphy and paleoenvironment of the first Ediacaran fossillagerstätte in South America View project 


\title{
Geology and Geomorphology of the Pantanal Basin
}

\author{
Mario L. Assine, Eder R. Merino, Fabiano N. Pupim, Lucas V. Warren, \\ Renato L. Guerreiro, and Michael M. McGlue
}

\begin{abstract}
What is an inlier sedimentary basin? What are the main mechanisms of sedimentary infilling? How do the depositional systems behave? And last, but certainly not the least, what geological events occurred in the last million years and continue to take place in the Pantanal area today? These issues are considered in this chapter, based on available geological, geomorphological, and geochronological datasets. The Pantanal is an active sedimentary basin with numerous faults and associated earthquakes. Movements along these faults cause subsidence on blocks within the basin, generating depressions that are highly susceptible to flooding, and also create accommodation space for sediment storage. One hypothesis on the origin of the Pantanal Basin relates the processes of subsidence with tectonic activity in the Andean orogen and foreland system during the Quaternary. Alternatively, the lack of geochronological data leaves open the possibility that the basin formed much earlier, perhaps during an interval of widespread tectonism in Brazil during the Eocene. The modern Pantanal depositional tract is composed of the Paraguay River trunk system, numerous fluvial megafans and interfan floodplains, and thousands of lakes, many of them integral to the Nhecolândia landscape. The Pantanal's geomorphology is most likely the product of climatic fluctuations and environmental changes that have been occurring since the Late Pleistocene.
\end{abstract}

M.L. Assine ( $\triangle)$, E.R. Merino, F.N. Pupim, and L.V. Warren

Universidade Estadual Paulista - Unesp, Instituto de Geociências e Ciências Exatas - IGCE,

Campus de Rio Claro. Avenida 24A, 1515, Rio Claro 13506-900, Brazil

e-mail: assine@rc.unesp.br

R.L. Guerreiro

Instituto Federal do Paraná - IFPR, Campus Assis Chateaubriand, Avenida Cívica, 475, Centro Cívico, Assis, Chateaubriand 85935-000, Brazil

M.M. McGlue

Department of Earth and Environmental Sciences, University of Kentucky, Lexington,

KY 40506, USA

I. Bergier and M.L. Assine (eds.), Dynamics of the Pantanal Wetland in South America,

Hdb Env Chem, DOI 10.1007/698_2015_349,

(C) Springer International Publishing Switzerland 2015 
Relict morphologic features like paleochannels have been preserved on the surfaces of abandoned lobes on several large fluvial megafans. After a period dominated by arid conditions in the Late Pleistocene, the Pantanal area experienced an episode of humidification and increasing fluvial discharge in the Early Holocene. This process promoted important modifications in the extant drainage system, for example, the avulsion of the Paraguay River that caused the Nabileque paleomeander belt to be abandoned. The landscape and sedimentary deposits of Pantanal Basin are "living" geologic records of changing rivers, avulsions, floods, and climate changes that occurred in the last several thousand years. Understanding the dynamics of these transitions is critical for unveiling the geologic history of the world's largest tropical wetland.

Keywords Avulsion, Fluvial megafans, Nhecolândia, Pantanal Basin, Tectonics and sedimentation

\section{Contents}

1 Introduction

2 From the Gondwana Assemblage to the Cenozoic Pantanal Sedimentary Basin

3 The Basin Infill and the Modern Depositional Tract Systems

4 Late Quaternary Landscape Variability

5 The Nhecolândia Landscape Enigma

6 Faults Constraining Sedimentation and Frequently Flood Areas

7 Conclusion

References

\section{Introduction}

The Pantanal Basin is situated in the Upper Paraguay River depression, which is located mostly within west-central Brazil, but it also extends into frontier territories belonging to Bolivia and Paraguay (Fig. 1). With a surface area of approximately $150,000 \mathrm{~km}^{2}$ [2] and relief ranging from 80 to $200 \mathrm{~m}$, the vast network of Pantanal floodplains are connected with the Chaco floodplains (Paraguay) to the southwest.

Bedrock rivers in the fringing source areas become alluvial rivers within the Pantanal plains, and the basin has been progressively filled with sediments carried by these rivers from the surrounding plateaus and dissected marginal lowlands (Fig. 2a). Sedimentation occurs in a large alluvial depositional tract comprised of the Paraguay River plain and several fluvial megafans. Sediment infill of the modern basin has led to the formation and persistence of large flood-susceptible areas that host rich aquatic ecosystems, which has led to the development of one of the most important tropical wetlands on the planet [3, 4]. The Pantanal experiences widespread and prolonged seasonal flooding from January to June, but with 

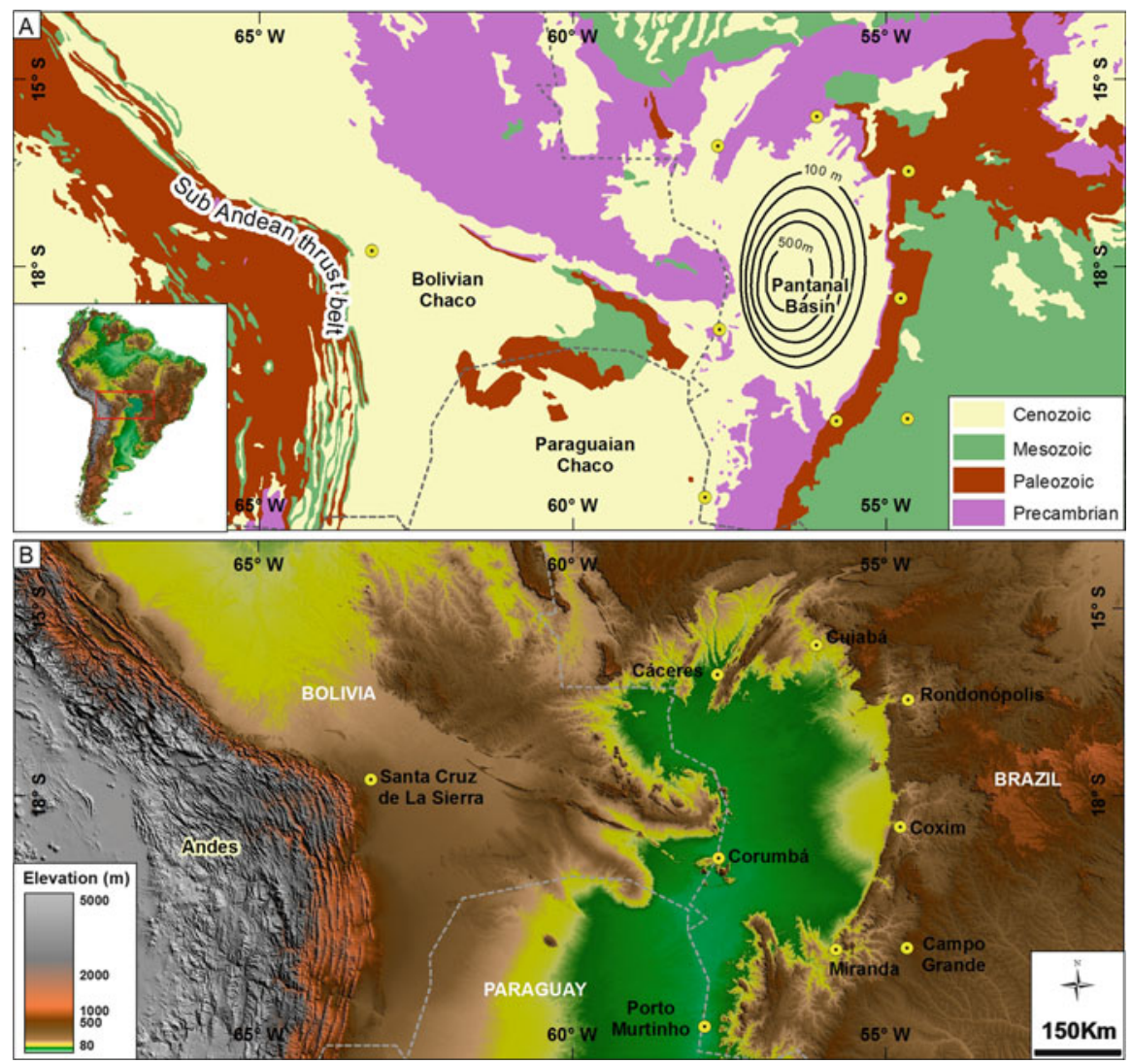

Fig. 1 Location of the Pantanal Basin. (a) Geological map (sediment isopach in meters from [1]). (b) Digital elevation model from Shuttle Radar Topographic Mission (SRTM)

diachronous flood peaks according to different geomorphologic floodplain zones [5].

What is commonly unknown about the Pantanal is the fact that the wetlands are situated in an active sedimentary basin with faults and associated earthquakes, which delimit the most flood-prone areas. Crustal movements along these faults promote differential subsidence of blocks within the basin, creating accommodation space that results in permanently flooded areas. The geological knowledge of the Pantanal Basin is still somewhat limited and studies are in their infancy, with few subsurface datasets (Fig. 2b) and scant information about the basin genesis, age and nature of the sediments, geomorphologic evolution, and modern sedimentation zones [6].

This chapter aims to present a summary of the geologic events likely responsible for the geomorphologic configuration of the Pantanal, from the uplift of the area following the fragmentation of Gondwana (lower Cretaceous) to the formation of the modern depositional tract during the Quaternary. Understanding these 

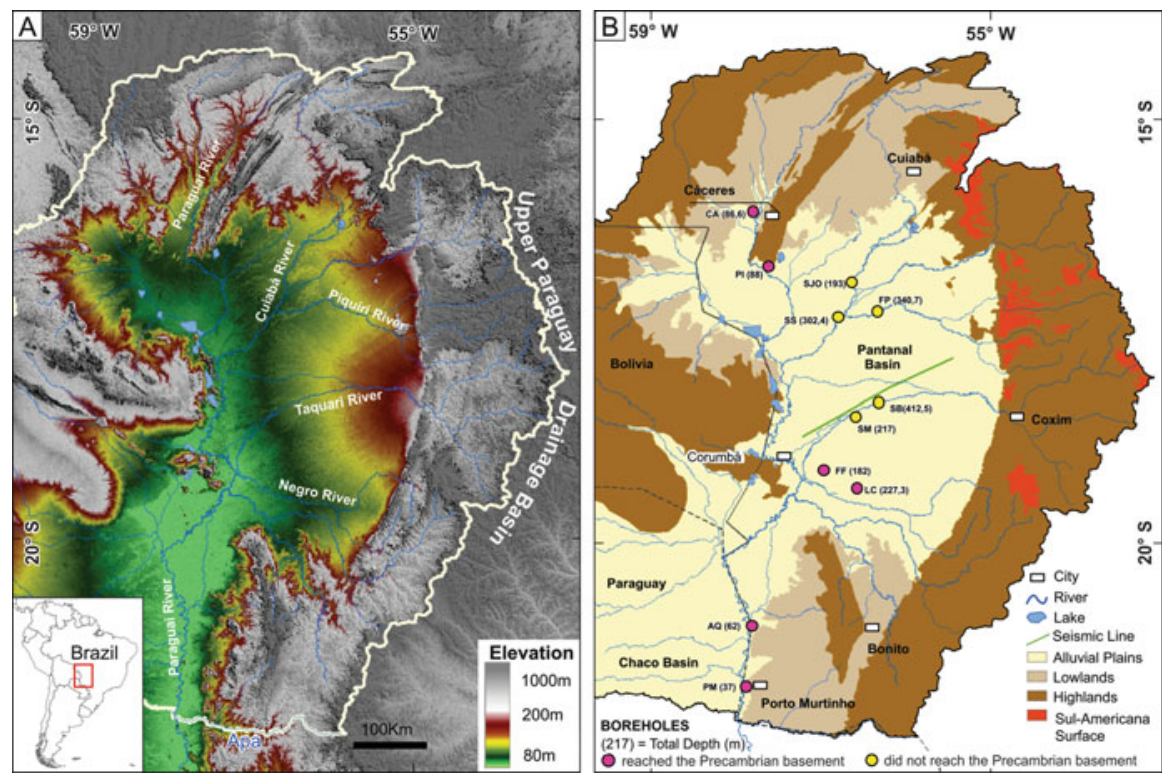

Fig. 2 Upper Paraguay drainage basin. (a) Digital elevation model from Shuttle Radar Topographic Mission (SRTM). (b) Map of geomorphological zones, showing the remnants of Sul-Americana surface on the surrounding highlands and subsurface data location within the Pantanal Basin

developments and environmental transitions is essential to revealing the extant sedimentological dynamics of the entire wetland.

\section{From the Gondwana Assemblage to the Cenozoic Pantanal Sedimentary Basin}

Following the assemblage of the Gondwana toward the end of Proterozoic Era (see [7]), the Pantanal region developed within the extensive domain of marginal basins that surrounded the supercontinent. This early Pantanal region was most likely a component of the Paleozoic-Mesozoic Paraná and Chaco sedimentary basins. Paleocurrent indicators, measured in sandstones of the Ivaí River Group (Ordovician and Silurian) and the Paraná Group (Devonian), suggest that there was depositional continuity between the Paraná and the Bolivian and Paraguayan Chaco basins [8, 9].

Paleozoic rocks have been almost entirely removed from the Pantanal area during the many strongly erosive dissection events during the Cenozoic. Today, few outcrops of Paleozoic rocks are present, which provide the limited evidence for the past connection between the Paraná and Chaco basins. One such example can be 
found in the Silurian Coimbra Formation, which is exposed in small hills to the west of Forte Coimbra in the Nabileque area of the southern Pantanal.

The inception of the Cenozoic era was marked by a relatively quiescent tectonic period in the Pantanal, especially from the Paleocene to the lower Eocene [10]. At this time, a prolonged interval of sustained geological degradation (weathering and erosion) reduced the relief of the eastern portion of Brazil into an extensive planation surface, which has been recognized in many areas and is widely known as the Sul-Americana surface [11-13]. This regional surface has been called by several names, such as the Cristas Médias surface [14], the Japi surface [15] in the state of São Paulo, and the Purunã surface in the state of Paraná [16]. In the final stage of its development, the Sul-Americana surface was marked by deep chemical leaching, sesquioxide enrichment, and laterite (ferricrete) formation.

The laterite profiles of the Sul-Americana surface exhibit characteristics that indicate a prolonged evolution under a humid tropical climate with abundant water [17]. Despite the scarcity of geochronological data, most of the available evidences indicate that the development of the Sul-Americana surface occurred from Paleocene to Early Eocene. For example, ${ }^{40} \mathrm{Ar} /{ }^{39} \mathrm{Ar}$ dating of deep weathering profiles in the "Quadrilátero Ferrífero," Brazil, returned ages of 51-41 Ma [18]. This age range is consistent with the climate record for the Eocene obtained from ocean sediments and microfossil isotope geochemistry [19], which suggests long periods of weathering and low denudation rates under hot and wet climatic conditions of the Early Eocene Climatic Optimum.

The geomorphology of southeast and south Brazil became more clearly delineated after the genesis and subsequent disruption of the Sul-Americana surface. The main intervals of tectonic reactivation were synchronous with development of the southeast Brazilian rift system in the Eocene [20]. Tectonic reactivations caused disparate uplift and rapid dissection of topography, which were most intense in the regions near the coast $[10,21]$. Remnants of the Sul-Americana surface have been recognized in the state of São Paulo at altitudes near 2,000 $\mathrm{m}$ in the Serra da Mantiqueira and Serra do Mar (Bocaina plateaus), decreasing in altitude toward the west [22, 23].

The flat-topped Central Plateau of Brazil (Goiás State) represents the Sul-Americana surface. Remnants of this geomorphic surface have also been recognized on the top of plateaus (e.g., planalto) surrounding the Pantanal at altitudes ranging from 600 to $800 \mathrm{~m}$ (Fig. 2). The Cachoeirinha Formation and several occurrences of thin detrital laterites dominate the sedimentary deposits atop these plateaus [24, 25]. Remnants of the surface are present on the Parecis Plateau to the north of the Pantanal, where ferruginous laterite horizons are found on the top of the plateau (700-800 $\mathrm{m}$ in altitude) [26]. The presence of deep laterite profiles over Neoproterozoic rocks at altitudes of approximately $1,000 \mathrm{~m}$ is also noteworthy on the flat top of the Urucum Massif, which is located on the western edge of the Pantanal Basin. Remains of the Sul-Americana surface in the surrounding plateaus are an uncontested piece of evidence in support of the major epeirogenic uplift before the inception of Pantanal Basin formation. 
Erosive downcutting by rivers initially formed the Upper Paraguay River, which reached the Chaco Basin through a passage between the highlands of the Bodoquena plateau and the Urucum Massif. The interior paleodrainage system was subsequently reorganized, and the Paraguay watersheds, located on the Pantanal's surrounding plateaus, became the headwaters of rivers running northward to the Amazonas and eastward into the Paraná drainage basin.

Deep erosion removed almost all of the Paleozoic and Mesozoic rocks from the Upper Paraguay River depression, forming an inlier of Precambrian metamorphic terranes surrounded by plateaus sculpted on Paraná Basin sedimentary rocks. Ab'Sáber [27] used the nomenclature boutonnière, a French term equivalent to inlier, to name this megastructure. Following the dissection of topography and creation of new relief, the main tributaries of the Paraguay River widened their drainage basins, giving rise to broad catchments on the eastern plateaus. Today, these rivers flow toward the west, in the opposite direction of the dipping slopes of Paleozoic sedimentary layers, which serves to form a cuesta-like morphology in the catchment area.

After the period of intense downcutting, processes of planation dominated during a period of tectonic quiescence from the Oligocene to Early Miocene, giving rise to a complex inter-plateau surface. Today, the so-called Cuiabana surface occurs on the top of Cuiabá River interfluves and decreases in altitude gently from the foothills of the marginal plateaus toward the Pantanal floodplain (250 $120 \mathrm{~m}$ above sea level). There is no consensus about whether the Cuiabana surface is a single and continuous surface throughout the Pantanal or, as some authors consider it, two different surfaces in the lowlands situated between the surrounding plateaus and the Pantanal floodplains [26, 28]. Detrital laterite deposits that document the final pediplanation phase are considered to be Pliocene-Pleistocene deposits [27], but their age has yet to be determined by absolute methods. Cosmogenic nuclide dating $\left({ }^{10} \mathrm{Be}\right)$ constrains the minimum age of detrital laterite sediments associated with the Cuiabana surface to be $500 \mathrm{ka}$ [29]. Recent ${ }^{10} \mathrm{Be}$ dating found similar minimum ages (maximum exposure age of $918 \pm 102 \mathrm{ka}$ ) and very slow erosion rates for the laterites, a key factor for the maintenance of the Cuiabana surface remains on the tops of hills [30].

The Pantanal Basin is located in the central part of the Upper Paraguay River inlier. The isopach map shown in the Fig. 1 does not reflect the real geometry of the Pantanal because it does not include the basin border nor the internal faults responsible for abrupt changes in the thickness of the sedimentary package. The basin geometry is marked by horst and graben structures, and the fault borders have dip displacements of hundreds of meters (Fig. 3). Faults are evident in the basin morphology, conditioning the occurrence of Precambrian terranes at the western edge of the basin and the modern alluvial drainage within the basin. The only available seismic section shows many small faults within the basin, displacing basement rocks of Precambrian age (see [7]). The Pantanal Basin is still tectonically active, with movements along fault planes, differential movement of blocks, and shallow earthquakes [6]. 

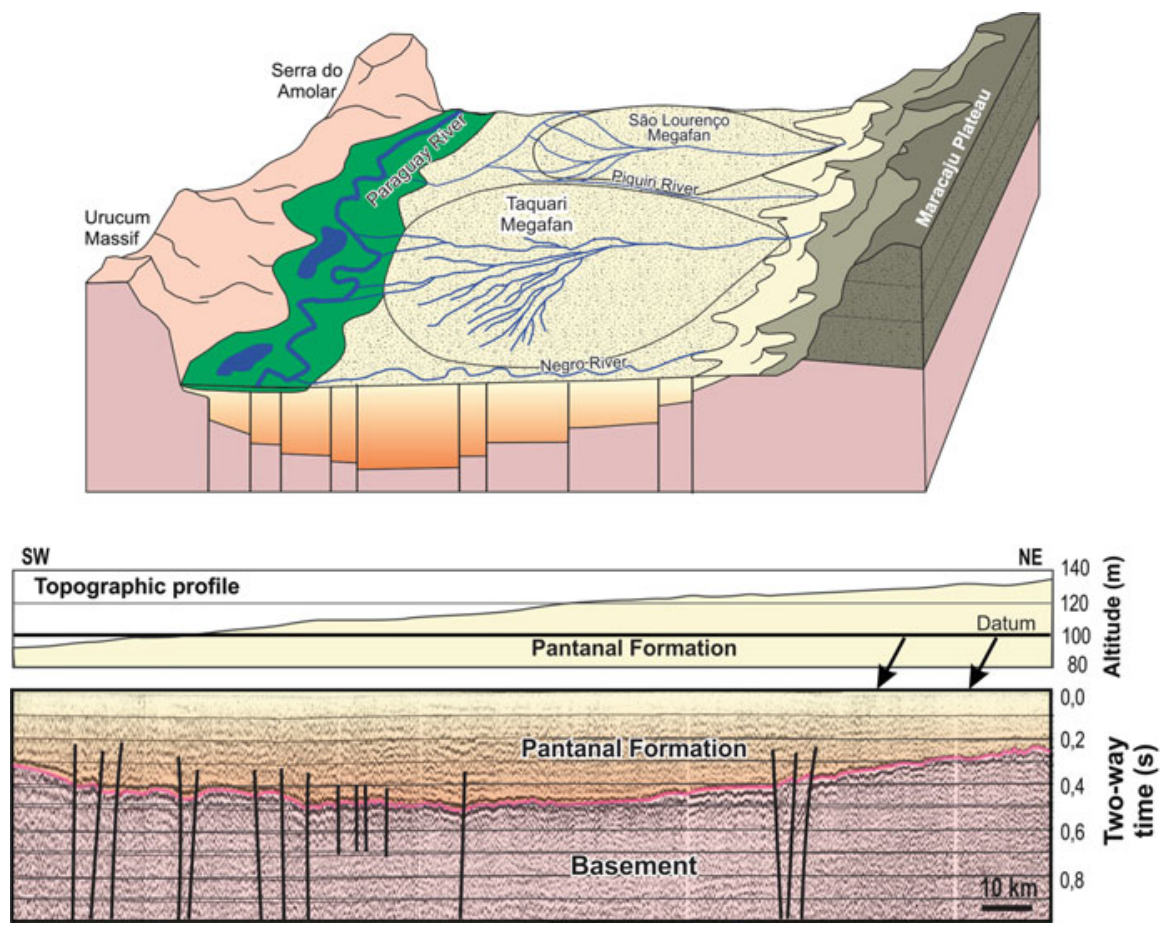

Fig. 3 Fault-structured basin. (a) Schematic block diagram illustrating the basin geometry. (b) Line drawing over the seismic section (location of the line on Fig. 2; seismic data from [31])

A crucial unanswered question regards the timing of basin formation. It is unknown when subsidence and infill of the basin with the siliciclastics of the Pantanal Formation took place. Taking into account a presumed PliocenePleistocene age for the Cuiabana surface and assuming that the basin's subsidence began after that particular planation event, Ab'Sáber [27] argued for a Quaternary age for the basin origin and inception of sedimentary infill. A Quaternary age was reinforced by Ussami et al. [1], who suggested the origin of the Pantanal Basin is associated with the last compressive event in the Andean orogen 2.5 Ma. Following this line of argument, the Cuiabana surface probably constitutes the basement of the Pantanal Basin, as represented in the schematic diagram of Fig. 4a showing the geologic evolution of the Pantanal area.

However, there is no information about the precise age of the oldest sediments of the Pantanal Basin, which reach at least $500 \mathrm{~m}$ in its depocenter. It is quite plausible to suppose that the basin is older, dating back to the Eocene, when an important tectonic event of uplift and basin formation took place in the southeast Brazil $[10,32]$, which was also coincident with an important tectonic reactivation phase in the Andes [33]. The sedimentary record of Cenozoic Taubaté Basin, one of the southeast Brazilian rift basins [20, 34, 35], consists of thick Eocene units. Based on chronological correlations with those events, an alternative hypothesis is presented 
4. Late Miocene - Quaternary (15-0 Ma): Tectonic reactivation and relief downcutting Basin subsidence and sedimentation

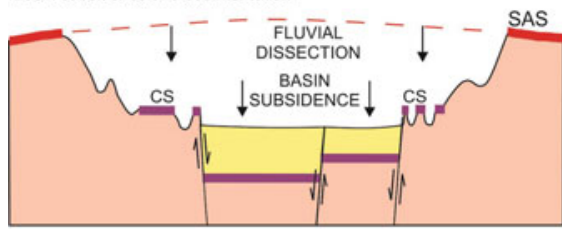

\section{Oligocene - Early Miocene (35-15 Ma):}

Tectonic quiescence, relief degradation and pedogenes Cuiabana surface CS) genesis: planation - laterization

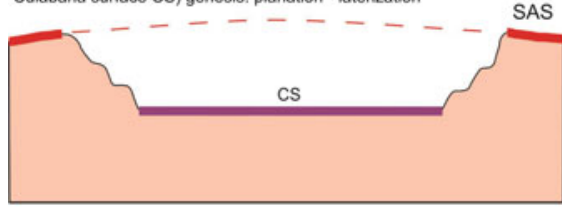

2. Late Paleocene - Late Eocene (60-35 Ma): Regional uplift and relief downcutting

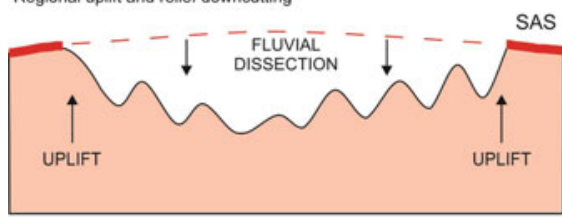

1. Early Paleocene (66-60 Ma):

Sul-Americana surface (SAS) genesis: planation - laterization

SAS

A) Basin initiation during the Neogene

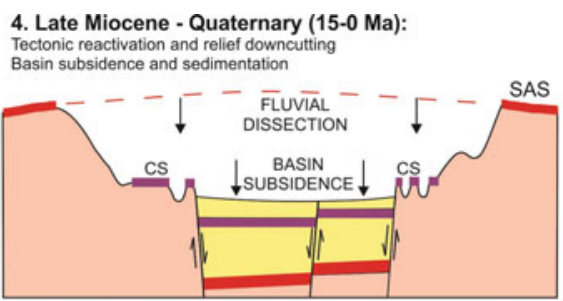

3. Oligocene - Early Miocene (35-15 Ma):

Tectonic quiescence, relief degradation and pedogenesis

Cuiabana surface CS) genesis: planation - laterization

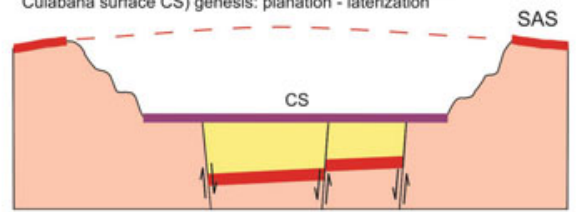

2. Late Paleocene - Late Eocene (60-35 Ma):

Regional uplift, relief downcutting andd basin subsidense

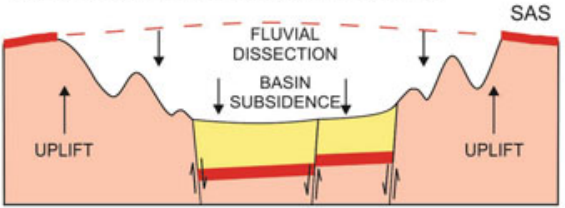

1. Early Paleocene (66-60 Ma):

Sul-Americana surface (SAS) genesis: planation - laterization

B) Basin initiation during the Paleogene

Fig. 4 Schematic diagrams of the Pantanal geologic evolution. (a) Basin initiation during the Neogene. (b) Basin initiation during the Paleogene

in the schematic diagram of Fig. 4b, which shows a model of geologic evolution in which the Pantanal Basin formed during the Paleogene by brittle tectonics. In this model, subsidence and sedimentation began in the Eocene, synchronously with epeirogenic uplift and tectonism that disrupted the Sul-Americana surface, and relicts from this surface are notionally represented on the basin floor and presently covered by the veneer of Cenozoic alluvial deposits.

The mechanism of basin formation has long been associated with Andes tectonics, an idea first presented by Almeida [36]. More recently, the basin formation was related to the Andean foreland system, more specifically to extensional stress at the forebulge [1, 37]. In contrast, Horton and DeCelles [38] presented a subsidence model in the back-bulge domain of the Andes foreland system, which includes the Chaco Basin as the foredeep area. The hypotheses that link the basin origin to the Andean tectonics are very elegant and exciting, but some of the models assume a forebulge position far away from the thrust front (700 to $1,000 \mathrm{~km}$ ) and thick lithosphere (100 to $150 \mathrm{~km}$ ). The question is unsolved, and new information must 
be considered to understand the basin formation in detail, such as the negative velocity anomalies of seismic wave propagation at different lithosphere depths below the Pantanal region [39].

\section{The Basin Infill and the Modern Depositional Tract Systems}

The subsurface data are restricted to eleven boreholes drilled in the 1960s by Petrobras. Unfortunately, the destination of cuttings and cores of these boreholes are unknown and the only information available to the public derives from Petrobras internal reports [40,41]. The SB-1 borehole drilled $412.5 \mathrm{~m}$ of the Pantanal Formation but did not reach the basement (Fig. 2). The lithologic data from this well reveals a monotonous stratigraphic stacking composed almost entirely by immature, fine- to coarse-grained sandstones, exhibiting a subtle tendency of fining upward. The lower section was composed dominantly of coarsegrained sandstones with occasional pebbly sands to conglomeratic intervals. Sandstones are white, yellowish, or brownish, angular to subrounded, with frequent ferruginous cementation and iron oxide concretions. Fine-grained intervals occur locally and are characterized by brown-to-yellowish sandy mudstones, which are most well expressed in the FF-1 well. Chronostratigraphic data are not available, and for this reason, there is no information about the age of the drilled sections.

Lithified debris flow deposits, as well as calcretes and ferricretes, are commonly associated with pediment surfaces in the foothills of highlands surrounding the modern depositional sites. These deposits are not well studied, but collectively they are considered to be Pliocene-Pleistocene in age. Among them, coarse sandstones and matrix-supported conglomerates related to coalesced gravity flow and alluvial fan facies form piedmont slopes on the foothills of the eastern tableland escarpments. Locally, as in the vicinities of the Corumbá urban area, there are siliciclastic and carbonate deposits (tufa) with impressions of angiosperm branches and leaves, as well as gastropod shells of undetermined ages, collectively classified as the Xaraiés Formation [42].

The modern depositional landscape is heterogeneous, which led some authors $[2,43,44]$ to subdivide the Pantanal wetland in distinct areas based on diverse criteria like landscape features, flooding dynamics and hydroperiods, flowing rivers, and local names (Fig. 5). The wetland heterogeneity reflects peculiarities of different systems within a huge depositional tract dominated by alluvial sedimentation, where the Paraguay River is the trunk system that collects waters from the entire Upper Paraguay Basin (Fig. 6).

Flowing from north to south, the Paraguay River floodplain exhibits very complex geomorphological characteristics because the river crosses different geological domains and interacts with other depositional systems. Before entering the Pantanal Basin domain, the Paraguay River flows in an aggradational meander belt 

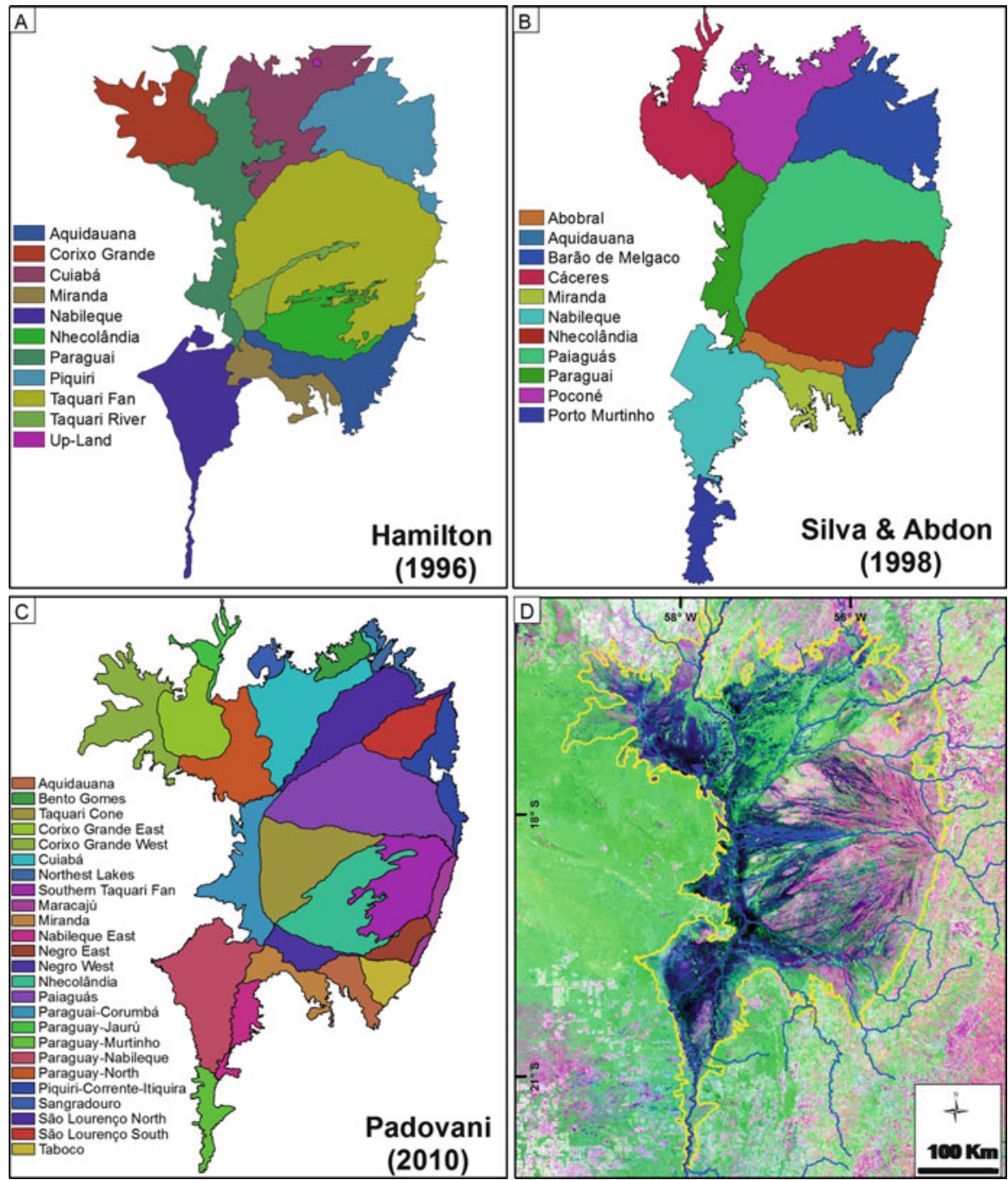

Fig. 5 Three geographic subdivisions proposed for the Pantanal and the outer limits of the wetland adopted in this chapter (Satellite image MODIS from October 2008)

approximately 4-6 km wide, built within a north-northeast-oriented incised valley on Precambrian crystalline rocks (Paraguay-Caceres river plain in Fig. 6). The river forms a fluvial megafan at its entrance into the Pantanal lowlands, because of a loss of valley confinement and decreasing topographic gradient. Paleochannels are preserved on the surface of presumably Pleistocene-aged abandoned fan lobes, forming cross-paleodrainage networks [91]. The topographic gradient abruptly diminishes at the base of the modern depositional lobe and the Paraguay fluvial plain style changes at this locality. 


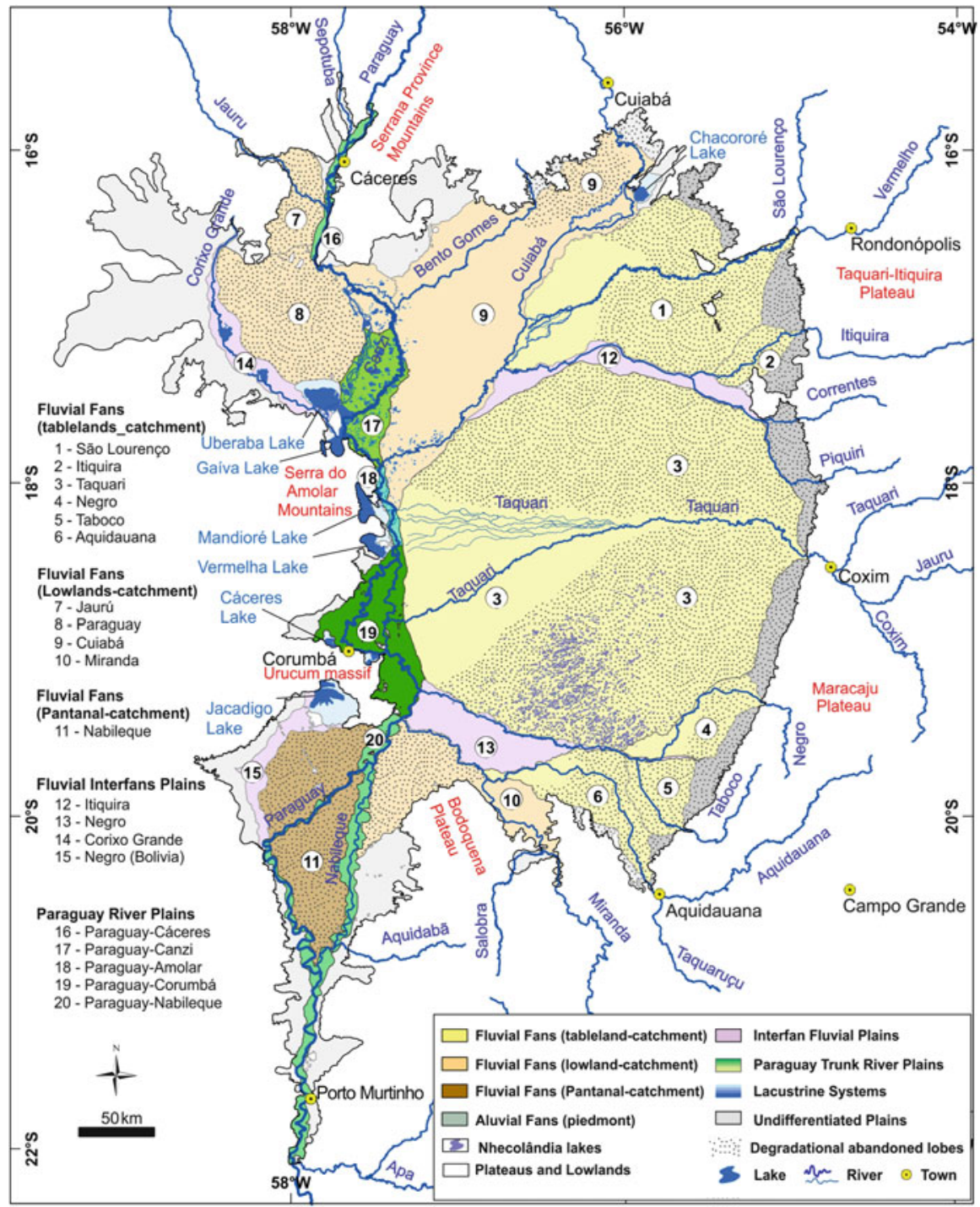

Fig. 6 Depositional tract systems of the Pantanal Basin [45]

Downstream, the river meanders within a large floodplain, characterized by abandoned meander channels and punctuated by hundreds of small lakes, whose water levels fluctuate in response to annual flood cycles. This fluvial-lacustrine plain (Paraguay-Canzi river plain in Fig. 6) drains waters derived from the Cuiabá River megafan, from nearby hills and undifferentiated marginal plains, and from peripheral channels of the Corixo Grande interfan system. 
The Paraguay River floodplain pattern changes in the Serra do Amolar area, where the plain becomes narrow and the river flanks mountainous Precambrian crystalline terranes on its right margin (Paraguay-Amolar river plain in Fig. 6). Aggradation in the meander belt dammed waters coming from Bolivia territory, possibly leading to the formation of the Mandioré and Vermelha lacustrine systems on the right margin of the Paraguay River [46], although the exact mechanism of lake formation is still poorly known. These lakes, surrounded by mountainous Precambrian rocks of the Amolar massif, keep important records for the reconstruction of environmental changes in the Late Quaternary in the Pantanal, a theme discussed in McGlue et al. [47].

The Paraguay River floodplain broadens downstream from the Mandioré Lake to its confluence with the Miranda River (Paraguay-Corumbá river plain in Fig. 6). The river forms a modern meander belt in this reach, superimposed on paleolandforms that formed in distinct preterit hydraulic conditions [48]. After the Miranda River confluence, the Paraguay River crosses into the Nabileque megafan and flows in a narrow, well-defined meander belt incised into Pleistocene-aged deposits. The area is a structural high between the Pantanal and the Chaco basins, where sediment thickness is less than $100 \mathrm{~m}$ and small hills of basement rocks crop out. Most of the Nabileque megafan is subject to erosional degradation, but abandoned lobes can be recognized by the existence of an intricate network of distributary paleochannels on its surface (Fig. 7).

The Paraguay River is the trunk system, but most of the deposystem tract is composed of fluvial megafans (Fig. 6). Many megafans are formed by rivers with catchment areas in the dissected sedimentary tablelands located to the east of the Pantanal, where deep fluvial erosion of Paleozoic and Mesozoic rocks has resulted in large sediment yields. Crossing sharp escarpments and leaving the catchment area situated on the plateau, these rivers form huge megafans by depositing their sediment loads due to much reduced topographic gradients on the plains within the Pantanal Basin. The Taquari is the most notable of the Pantanal's megafans, because of its unusual quasi-circular shape and vast area of $\sim 50,000 \mathrm{~km}^{2}$, making it easily recognizable on satellite images $[50,51]$, but also notable are the megafans formed by the rivers São Lourenço [52, 53] and Aquidauana [54]. These megafans are complex depositional systems, characterized by modern distal depositional lobes and feeder rivers entrenched in upper fan Pleistocene-aged alluvial deposits. Paleochannels are present on the surfaces of these abandoned alluvial fan lobes, providing evidence of successive avulsions during the Pleistocene, with associated deposition and merging of fluvial sand bodies, which make up the alluvial architecture of the Pantanal Formation (Fig. 8).

Besides the megafans mentioned above, the Cuiabá is another important system because of its dimensions, complexity, and presently active patterns of sediment accumulation [56]. In stark contrast to most of the other Pantanal megafans, the abandoned Cuiabá lobe is small and the modern depositional site is elongated and broad, with many crevasse splays along the main channel and abandoned channels and sandy lobes on the floodplain. Similar to the other megafans in the Pantanal wetland, the Cuiabá river belt is entrenched in the upper fan, where the river 

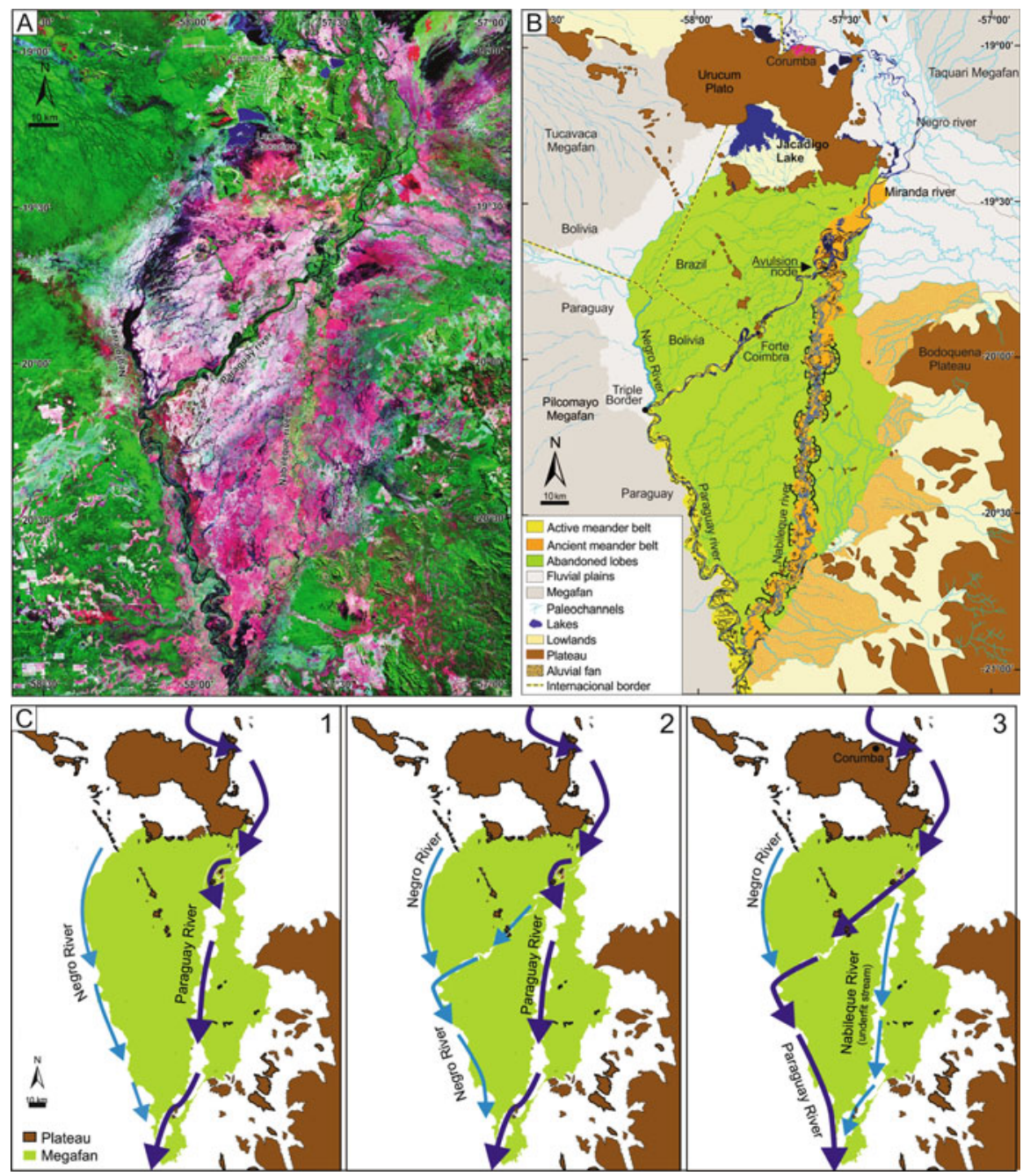

Fig. 7 Paraguay River meander belts (modern and ancient) cutting abandoned lobes of the Nabileque megafan (Modified from [49, 71]). (a) Satellite image Landsat Geocover Circas, RGB742, from June 2001 (dry season). (b) Geomorphologic zonation showing the actual and the ancient position of the Paraguay River. (c) Model of the Paraguay River avulsion

changes style from meandering to anabranching in some reaches. The altitudes range from approximately $160 \mathrm{~m}$ at the apex to $95 \mathrm{~m}$ at the confluence with the Paraguay River, resulting in a topographic gradient that is less than $0.20 \mathrm{~m} / \mathrm{km}$.

Interfan fluvial systems that are present in between megafans serve to collect water and sediments from these larger riverine landforms. The Piquiri River plain is a typical confined meander belt sandwiched between the Taquari and São Lourenço megafans. The Negro River interfan meander belt is another active sedimentary 

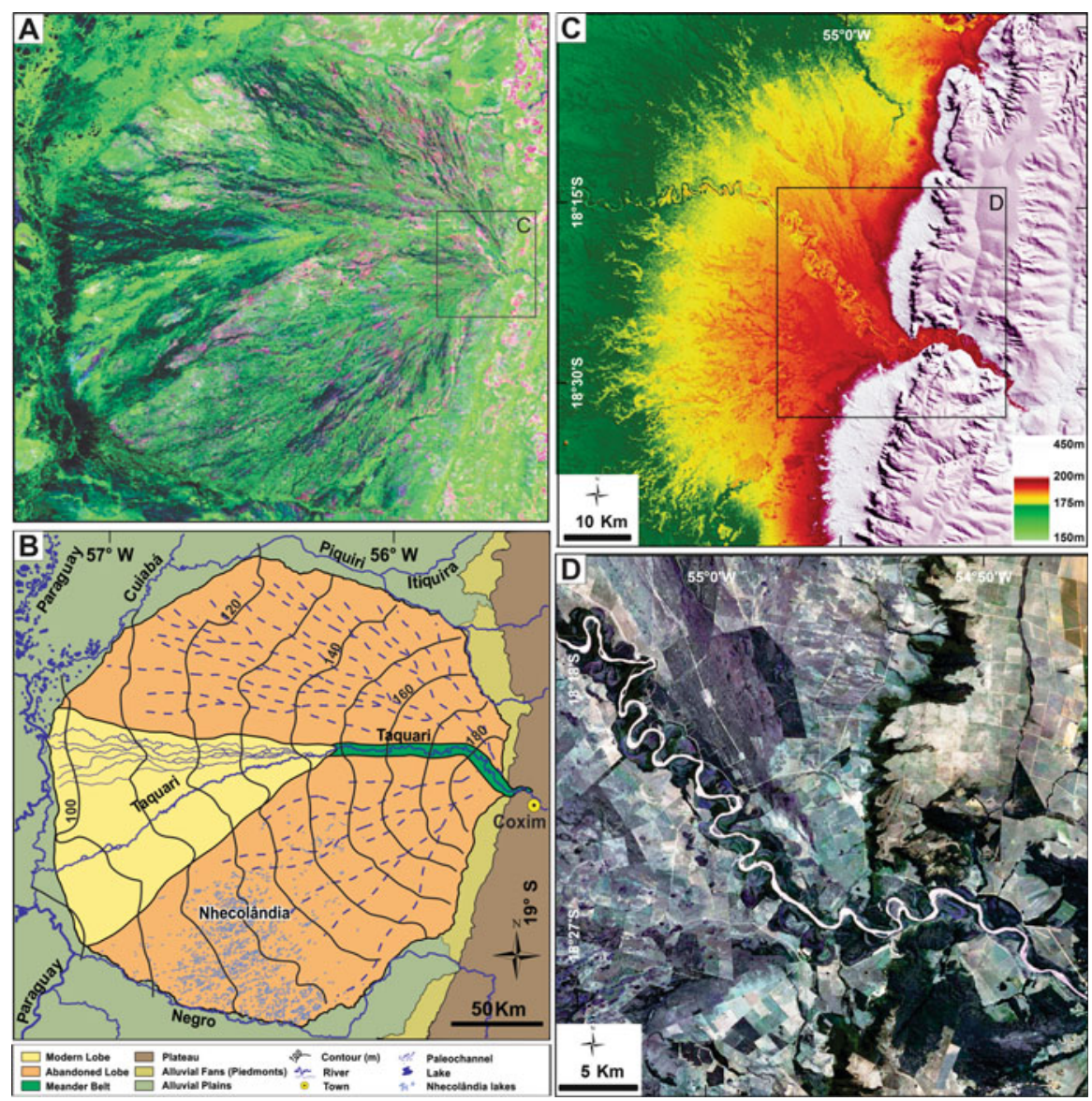

Fig. 8 Taquari fluvial megafan. (a) Satellite image MODIS/Terra MOD13Q1 R(MIR) G(EVI) B (Blue) from April 2011 (wet season). (b) Geomorphologic zonation showing abandoned and active lobes and the entrenched meander belt in the upper fan (Modified from [51, 55]). (c) Incision in the upper fan cutting a network of distributary paleochannels (digital elevation model from Shuttle Radar Topographic Mission (SRTM). (d) Actual confined meander belt (Basemap image ArcGIS Online)

system in between the Taquari to the north and the Aquidauana and Taboco fans to the south. The Negro River floodplain has a more complex configuration than the Piquiri, as the fluvial style changes downstream from an entrenched meander belt that progressively loses confinement to the west, where the river enters in a frequently flooded area and acquires an anabranching pattern. 


\section{Late Quaternary Landscape Variability}

The Pantanal landscape is the product of climatic fluctuations and environmental changes during the Late Quaternary [57]. Braun [50] was the first to mention that the Taquari megafan is mostly comprised of relict depositional landforms that developed under semiarid conditions of the Late Pleistocene. Similar interpretations were put forward in later publications [58, 59]. Ab'Sáber [27], based on regional paleoclimate correlations, argued that the climate was desert-like during the Last Glacial Maximum (LGM), with sparse vegetation (caatinga) and intermittent torrential flows along the alluvial fans. These early insights led Clapperton [60] to assume that the modern landscape had been formed during a period of aridity in the Late Pleistocene.

In the central portion of South America, environmental conditions of dry climate and highly seasonal rainfall are mainly ascribed to the Late Pleistocene; this interval is associated with intense fluvial system activity, elevated coarse sediment yield ([61, 92]), and concomitant development of megafans in the Bolivian Chaco [62]. Sediment radiocarbon dating and palynological data support the interpretation of arid conditions in the Late Pleistocene of Pantanal $[63,64]$. The combination of poor vegetation cover, strong seasonal precipitation, torrential flow regimes, and high sediment supply from the fringing catchments to the Pantanal Basin led to the development of large distributary systems. Paleodrainage networks are still preserved on the surface of the Taquari megafan abandoned lobes [6, 55, 57, 65]. Wellpreserved Late Pleistocene-aged distributary braided paleochannels on the surface of abandoned fan lobes in the upper portion of the São Lourenço megafan are excellent examples of this relict paleodrainage style (Fig. 9) [53].

An important environmental transition occurred near the end of the Pleistocene, where the climate was thought to be relatively dry and colder than present, to wetter and warmer conditions in the Holocene [27, 57]. With increasing fluvial discharge during the Early Holocene [66], river incision occurred at the apical portions of the megafans fed by the rivers Taquari, São Lourenço, and Aquidauana, which all have catchments on sedimentary plateaus located to the east of the Pantanal Basin. The incision moved the intersection point of these systems toward the west, and the modern depositional lobes established in the lower fan settings, with apical lobe positions immediately downstream of the entrenched valleys. Deposition on the modern lobes caused a rise of river equilibrium profiles and aggradation within the incised valleys, which at that time were characterized by the presence of confined meander belts in the upper fan of the Taquari, São Lourenço, and Aquidauana megafans.

As proxy and radiocarbon data $[63,64]$ are restricted to the Gaíva and Mandioré lakes, situated on the western margin of the Paraguay River and influenced by environments and sediment provenance of the Bolivian Chaco, a very relevant issue to understand the geomorphological evolution of the Pantanal landscape arises: when did the Pantanal become the environment we know today as the world's largest tropical wetland [67]? 

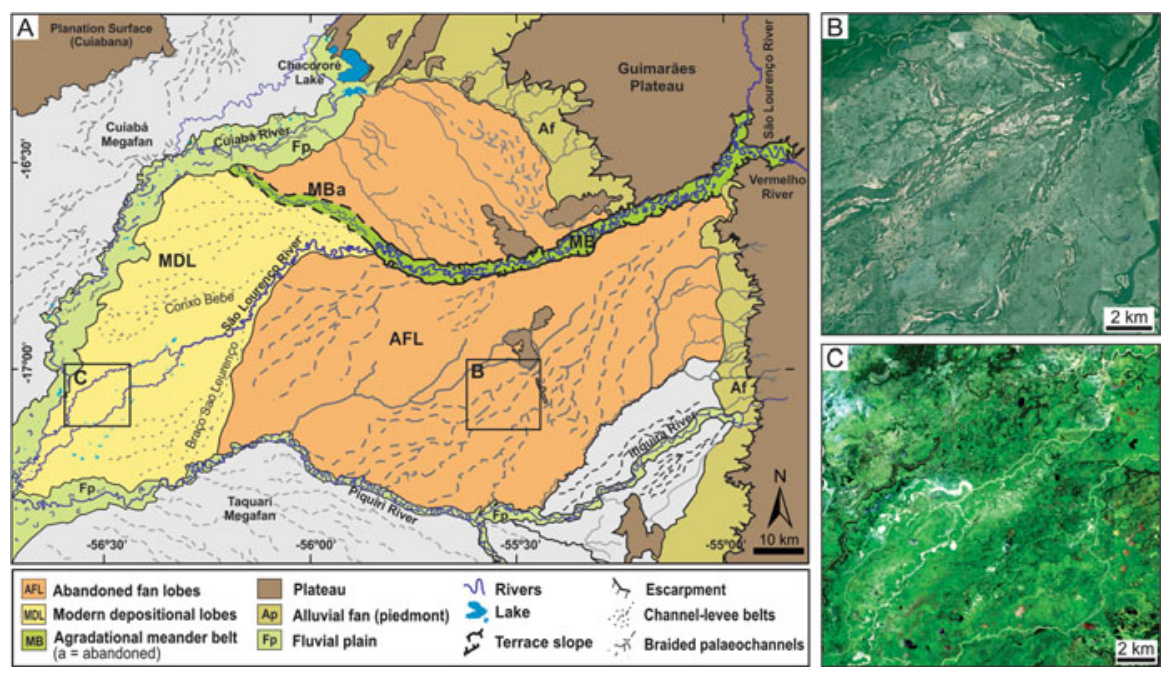

Fig. 9 São Lourenço megafan. (a) Geomorphologic zonation (Modified from [52, 53]). (b) Distributary braided paleochannels. (c) Distributary and anabranching channels that characterize the modern depositional lobe (Satellite image SPOT 5, 2007/2008 mosaic)

The expansion of the Pantanal flooded areas may have begun from the Paraguay River fluvial plain, once it enters into lower relief within the basin; importantly it also serves as the trunk river collecting water from the surrounding plateaus. However, the Paraguay plain has changed in a partitioned and irregular way, which points to the formation of the Negra and Castelo lakes, respectively, at 10,200 and 5,100 years before the present [68,69]. The rising of the regional groundwater level, controlled by the Paraguay River fluvial plain, which is the base level for the majority of the megafans and fluvial plains of the Pantanal, increased the flooded areas from downstream to upstream for all of the surrounding systems. Humidification was not synchronous nor linear in time, since minor oscillations occurred in the Holocene [64], causing biogeographical changes, especially the revegetation of the area (see modern vegetation on Pott and Silva [70]).

The Paraguay River is confined in a narrow meander belt that is entrenched on Pleistocene deposits in the Nabileque megafan. The modern river course has resulted from a major avulsion that commenced during the mid-Holocene, which caused the Nabileque meander belt to be abandoned (Fig. 7; [49, 71]). The visually striking north-south-oriented paleomeander belt is now occupied by the Nabileque River, an underfit river that is much smaller than the abandoned channels found in the paleomeander belt where it flows.

A similar avulsion phenomenon was discovered for the Paraguay River system, north of Corumbá city. Recognizing three distinct depositional associations, based on cross-cutting relations, Macedo et al. [48] established a relative succession of geomorphic events: (1) an abandoned drainage network that consisted of anabranching, elevated ridges of channels and levees that formed during an initial 
period of low river discharge; (2) a set of north-south paleomeander belts cutting through the channel-levee ridges that records an increase of river discharge, probably from the lower to the middle Holocene; and (3) an important avulsion event, probably from the middle to late Holocene, that shifted the river to its present-day meandering belt, forming the Paraguay Mirim underfit river.

Paleo-hydrological changes during Holocene are imprinted on many other Pantanal plains rivers, for example, in the Miranda River, where Merino et al. [72] recognized superimposed belts with different channel widths and meander-bend morphology. All of this evidence of change needs to be dated by absolute techniques and integrated with the various observations of the Paraguay River plain and its marginal lakes in order to reconstruct the way and trends of changing.

\section{The Nhecolândia Landscape Enigma}

An intriguing feature of the Pantanal Basin geomorphology is the exotic Nhecolândia landscape, which is easily identified through satellite image analysis (Fig. 10). Located in the southern portion of the Taquari megafan, the Nhecolandia is characterized by the presence of more than 10,000 shallow lakes bordered by sand ridges. The lakes are circular to elliptical shapes and they are usually elongated in the NE direction.

Most of the lakes are of freshwater hydrochemistry, invaded by seasonal floodwaters and colonized by a variety of aquatic macrophytes. Approximately $10 \%$ of the lakes are isolated from the surface drainage and characterized by the presence of brackish to saline water, which may present greenish color due to a proliferation of cyanobacteria. The existence of alkaline lakes was reported for the first time by Cunha [73], who highlighted the presence of bicarbonate, chlorinated, and sodic waters, with $\mathrm{pH}$ values ranging between 8 and 10. The saline lakes are devoid of aquatic vegetation and characterized by white-sandy beaches.

Tributary ephemeral (vazantes) and permanent (corixos) streams are superimposed on the landscape of lakes and sand ridges, connecting the freshwater lakes and draining floodwaters to the Negro River at the southern border of megafan. The interaction between seasonal flood waters, different floodplain morphologies, and fluctuations of groundwater level controls the location of distinct vegetation, including forests, savannas, wild fields, herbaceous vegetation, aquatic macrophytes, and marsh vegetation [74].

Several authors have attempted to explain the origins of this peculiar Pantanal landscape and the salinity of the isolated ponds. The first attempt to interpret the genesis of this landscape was made by Almeida [42], who suggested a reworking of fluvial sediments by eolian processes, based on the predominance of fine-to-very fine, white, well-sorted, clean, and bimodal sands. In this way, Almeida [36] attributed the origin of the Nhecolândia lakes to depressions caused by wind 


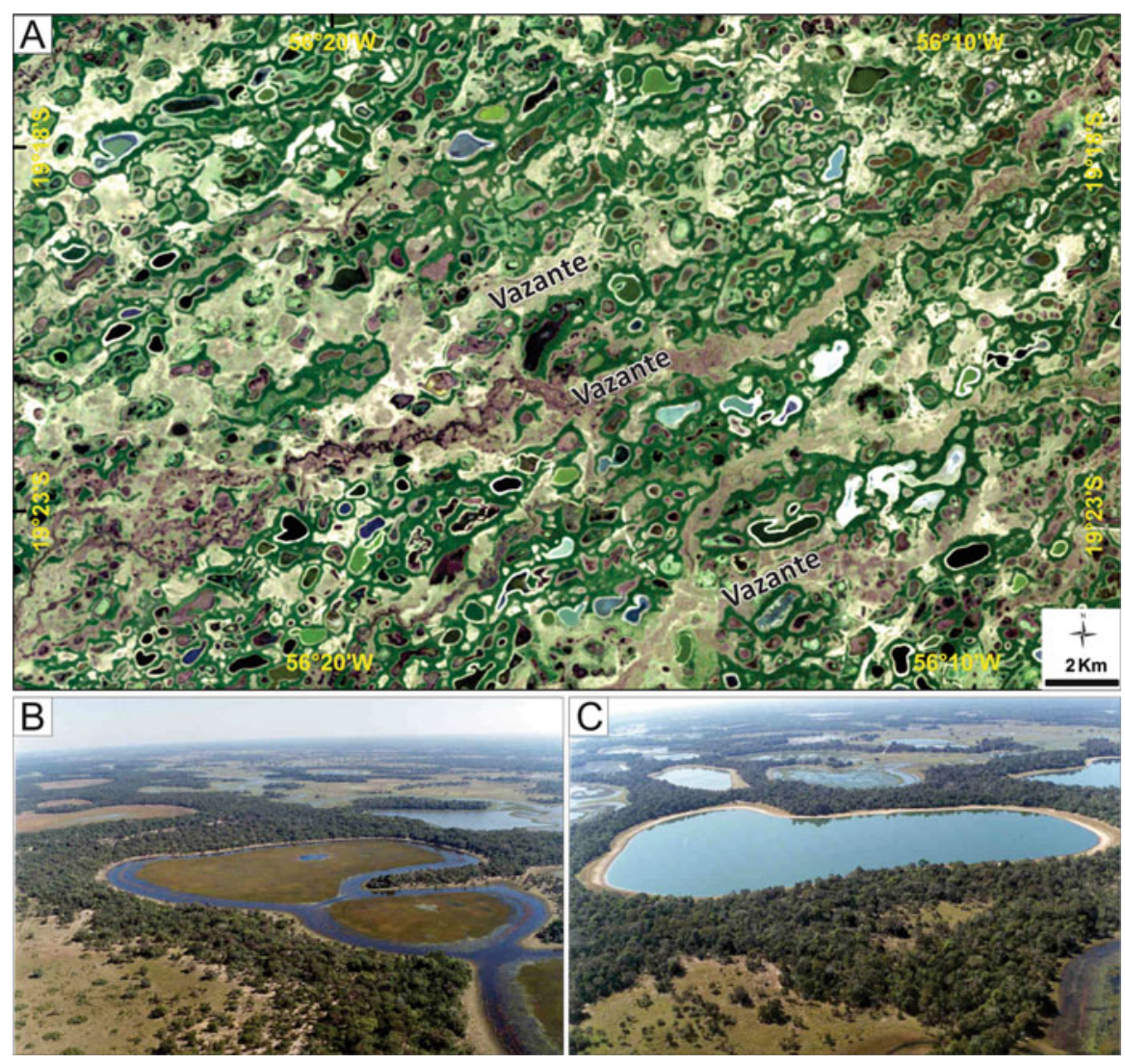

Fig. 10 Nhecolândia landscape. (a) Typical morphology of NE-SW-oriented lakes with superimposed modern tributary shallow streams (vazantes) in a Landsat TM 5 image RGB321 from July 2008. (b) Connected freshwater lakes with characteristic aquatic vegetation. (c) Saline lakes with sandy beaches

deflation processes, and Valverde [75] suggested that the ridges are vegetated dunes that formed during earlier desert conditions.

Wilhelmy [76] proposed a completely different genesis hypothesis, suggesting that the lakes formed by confinement of floodplain areas due to cross-cutting and overlapping of marginal levees. Successive lateral migration of the rivers would be responsible for the myriad lakes, an origin hypothesis that was later adopted by Ab'Sáber [27].

Braun [50] viewed the lakes as product of depressions in the alluvial plains developed over karstic terrains. However, this interpretation was considered unlikely by Por [67], arguing that, although karstic environments are common on the Bodoquena plateau surrounding the southern Pantanal, the geological substratum of Nhecolândia consists of thick layers of unconsolidated sandy sediments. 
Interpretations based on eolian processes returned to favor in the 1980s. Making use of radar imagery, Klammer [59] interpreted the existence of two trends of fossil longitudinal dunes aligned, NNE-SSW and NNW-SSE, that presumably formed under a regime of constant NNE and NNW paleowinds. Based on satellite images, Tricart [58] interpreted the lakes as hollows produced by wind deflation, similar to those in the Argentine Pampas, and assumed past arid climates gave rise to the presence of saline lakes from relict sabkhas. Taking into account the aforementioned interpretations, the Nhecolândia lakes were considered saltpans in the review papers of Goudie [77] and Goudie and Wells [78]. A similar understanding led Clapperton [60] to consider that the Chaco-Pantanal region had an arid climate marked by the formation of dune fields, which resulted from a far south position of the South Atlantic Anticyclone in the terminal Pleistocene.

Despite the evidence and arguments for eolian processes acting in the genesis of Nhecolândia landscape, the origin of these lakes has remained a controversial topic. Some researchers argue that there is no evidence supporting the interpretation of eolian processes and products [79]. One of the greatest criticisms is based on the fact that typical wind-blown sedimentary deposits have not been found, such as dunes fields and cross-bedded sands.

In a test of the eolian hypothesis, no evidence of NNE- and NNW-oriented longitudinal dunes was found on satellite images [6,57], as identified in the radar images of Klammer [59]. From a sedimentological perspective, it has become clear that the sands do not exhibit the microscopic and morphological characteristics of mature desert sands. Rather, a mixture of grain populations with sediment provenance from Paleozoic and Mesozoic sandstones exposed in the source area was discovered [80]. However, the absence of longitudinal dunes and compositionally mature desert sands is not a sufficient evidence to abandon the notion of a role for eolian processes. It could be the case that the Nhecolândia landscape was dominated by sand sheets with localized lunettes [57], and deflation hollows could be inundated later, for example, accompanying a regional rise of the groundwater level, thus leading to lake formation.

The origins and timing of alkalization and salinization of pond water are another controversial issue. Tricart [58] attributed the salinity to past arid climates, while Ab'Sáber [27] ascribed it to the isolation of oxbow lakes. Alkalinization by recent and presently active biogeochemical [81] and geochemical processes [82-84] has recently been suggested to explain the peculiar composition saline lakes of Nhecolândia. Geochemical studies point out that the saline lakes are the result of equilibrium between water flows and geochemical processes, in which the saline water originates from concentration of fresh vadose zone and groundwater via evaporation [82-84]. New information about ecological and biogeochemistry dynamics of the Nhecolândia alkaline lakes is presented in Bergier et al. [85].

In summary, interpretations about the origin of the Nhecolândia landscape are mainly based on interpretation of satellite data (i.e., indirect), with little sedimentologic information and no reliable dating. New data sources and new lines of interpretation must be pursued in order to reconstruct the processes and events that 
have shaped the Nhecolândia landscape since the Late Pleistocene. Thus, the origin of the lakes and their morphology and hydrochemistry remains an enigma!

\section{Faults Constraining Sedimentation and Frequently Flood Areas}

Basin tectonics plays an important role in the development of the Pantanal landscape, particularly due to their impacts on base levels and topographic gradients. The Paraguay fluvial plain in the western margin of the Pantanal is structurally constrained by faults that separate the floodplain from the Urucum-Amolar dissected plateau. Near the Serra do Amolar, the Paraguay River runs on bedrock composed of Precambrian crystalline rocks of the Cuiabá and Corumbá groups.

To the south, the Paraguay River deflects approximately $90^{\circ}$ in the vicinities of the city of Corumbá, and its eastward flow is controlled by WNW-ESE normal faults. Low-grade metamorphic rocks of the Neoproterozoic Corumbá and Cuiabá Groups crop out on the footwall of the fault to the south, where altitudes reach $1,000 \mathrm{~m}$ in the Urucum Massif (see [7]). On the right margin of the watercourse in the Corumbá urban area, the river bank locally may be higher than $20 \mathrm{~m}$ and consists of Precambrian metamorphic rocks and colluvium capped by carbonates of the Xaraiés Formation.

Near the Corumbá city, the Urucum Massif is characterized by hills surrounded by cliffs and escarpments that are sustained by a capping laterite crust. This juvenile relief is strongly conditioned by faults and fractures and constitutes clear evidence of neotectonic activity along the western border of the Pantanal. Most of the valleys of this geomorphologic province are developed along linear discontinuities with a dominant NE-SW trend; some of these discontinuities are situated around $450 \mathrm{~m}$ above the medium topographic surface of Pantanal lowlands, therefore constituting true suspended valleys. In contrast to the uplifted areas and suspended valleys, the subsidence of fault blocks creates accommodation space and low areas subject to periodic flooding.

Several trends of active faults affect modern tributary streams (corixos and vazantes), conditioning the actual drainage and the water that flows on the surface of abandoned lobes. Quite remarkable are the fractures and faults oriented in a NESW direction, supposedly associated with the Transbrasiliano Fault System, a regional geotectonic suture recognized in the area by Soares et al. [86]. There are regional trends of lineaments crossing the Pantanal area, and many attempts have been made to define them using remote sensing (e.g., [87]).

Based on satellite remote sensing data, a study based on the effects of neotectonics on the drainage networks in the alluvial sedimentation revealed four main sets of geologic lineaments that constrain stream direction within the Pantanal wetland (Fig. 11). The NNW-SSE lineaments are well developed on the western margin of the basin, proximal to the flow of the Paraguay River. Particularly 

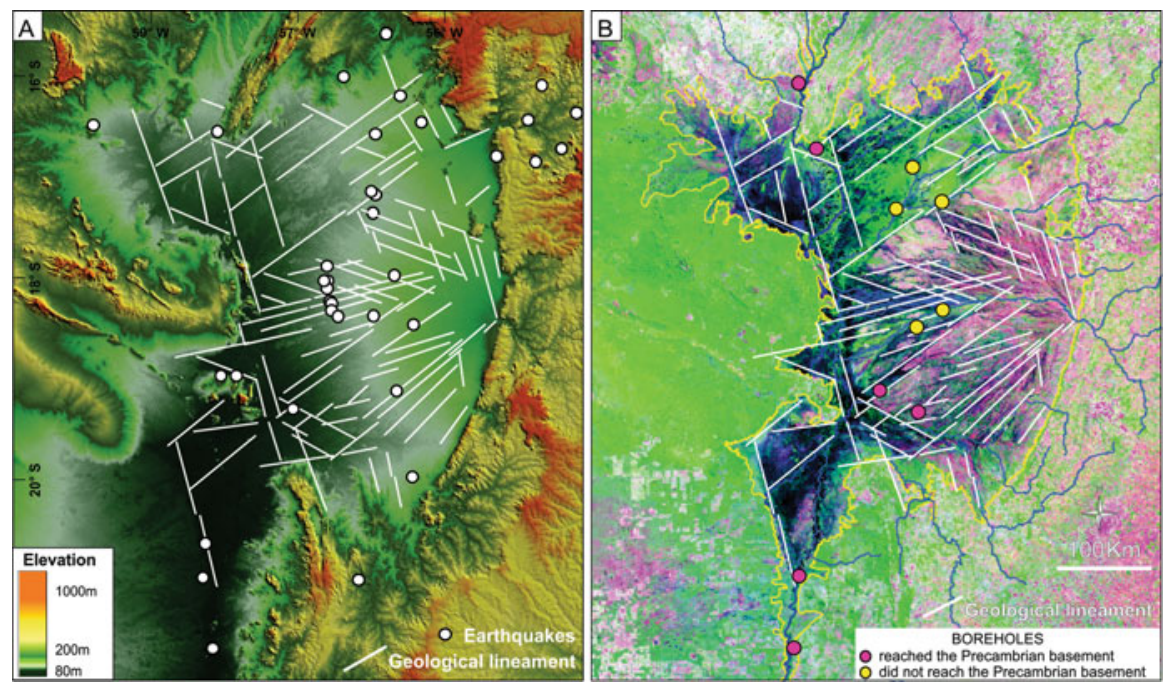

Fig. 11 Geological lineaments of the Pantanal wetland. (a) Digital elevation model from Shuttle Radar Topographic Mission (SRTM). (b) Satellite image MODIS from October 2008, MOD13Q1 R(MIR) G(EVI) B(Blue)

impressive are the ENE-WSW lineaments, which are clearly recognizable as they cross the modern depositional lobe of the Taquari megafan, where the important Caronal avulsion is in progress.

The southern boundary of the Taquari modern depositional lobe is controlled by NE-SW faults, suggesting that this limit is also associated with the Transbrasiliano Lineament. In this context, the hanging wall block is located on the NW side of the regional fault system, and it constitutes an area subject to high sedimentation rates and strong annual floods.

Subsiding fault blocks are presently creating accommodation space for sedimentation and flooding not only in the modern depositional lobe but also in the lower Negro River course. Perhaps a more striking example of this process can be found along the north portion of the Pantanal, where an important subsiding area, controlled by NE-SW and NNW-SSE faults, is receiving sediments carried from the source area by the rivers Cuiabá, São Lourenço, and Paraguay (Fig. 11). This is a long-lived subsiding area, and of the three deep $(\sim 340 \mathrm{~m})$ boreholes drilled here, none reached the basement (Fig. 2). This area is an active depositional site as well and is subject to prolonged flooding events.

Downstream the mouth of the Miranda River, the basement is uplifted and controls the regional base level of the Pantanal, acting as a natural dam for the Pantanal waters. This is one of the reasons for the existence of large, frequently flooded areas in the Paraguay and Negro river floodplains. In the Nabileque megafan, the Paraguay River runs in a meander belt that cuts Pleistocene deposits of the Nabileque megafan. In this area, the sediment thickness is less than $100 \mathrm{~m}$, 
and the basement rocks are exposed in isolated hills surrounded by the Nabileque floodplain, as observed in Forte Coimbra and Fecho dos Morros localities.

Recent movements along fault planes have resulted in earthquakes with epicenters located in the Pantanal plains. An earthquake occurred in 1999, with an epicenter near the apex of the modern depositional lobe of the Taquari megafan, and produced a focal mechanism that indicates an E-W compressive stress [88]. Another recent earthquake occurred in 2009, also situated within the Taquari megafan, revealed an epicenter $6 \mathrm{~km}$ deep and focal mechanism indicative of a NESW compression [89]. These data are consistent with intra-plate seismicity associated with regional maximum horizontal stress directions in central Brazil, characterized by E-W to SE-NW regional compression [90]. However, probably this contemporary regime of stress is associated with tectonic process that is modifying the basin; these are most likely distinct from the tectonic movement that was responsible for basin initiation. As mentioned previously, the tectonic stresses' history of events responsible for basin formation remains unclear and awaits future in-depth studies.

\section{Conclusion}

Pantanal is an active sedimentary basin with faults and associated earthquakes that delimit the most flood-prone areas. Some new information about the importance of tectonics with respect to the dynamics of the Pantanal depositional system were presented in this chapter. It was emphasized that faults are evident in the basin morphology, conditioning the occurrence of Precambrian terranes at the western edge of the basin and the modern alluvial drainage within the basin. Moreover, crustal movement along these faults causes subsidence of blocks within the basin, creating accommodation space that results in permanently flooded areas. However, a lot of work must be done to comprehend the nature, geometry, and evolution of the basin, as well as the interaction between the geological substrate and the superficial geomorphologic processes. Many questions remain unanswered, awaiting the availability of appropriate tools and new techniques, which is likely to include a dense grid of high-resolution subsurface data. The structural framework of the Pantanal Basin is not yet outlined, and little is known about its neotectonics and its stress field regime.

The basin formation has been related to Quaternary processes associated with the Andean convergent orogen and foreland system, more specifically to extensional stress at the forebulge or a shallow subsidence area in the back-bulge domain, which includes the Chaco Basin as the foredeep area. Nevertheless, as there is no information about the age of the oldest sediments of the Pantanal Basin, it is plausible that the basin initiation dates back to the Eocene, when an important tectonic event of uplift and basin formation took place in the southeast Brazil. The conclusion is that the geological knowledge about the Pantanal Basin formation and evolution is still in its infancy. 
Many of the existing morphological features are, in fact, relict forms overprinted on the modern landscape as evidence of distinct past conditions and environments. The Pantanal landscape is the product of climatic fluctuations and hydrological changes that occurred during the Late Quaternary. Radiocarbon dating and palynological data support the interpretation of arid conditions in the Late Pleistocene. The ancient paleodrainage style of this old and arid Pantanal is preserved on the surface of abandoned fan lobes in the upper portion of the São Lourenço and Taquari megafans.

Nevertheless, active processes are continually changing the Pleistocene landscape, either by the erosion of relict landforms or by modern sedimentation in the depositional lobes of fluvial megafans, as well as along the Paraguay River floodplain and tributary interfan river belts. The modern Pantanal wetland emerged due to climate change and increasing fluvial discharge during the Early Holocene. Since then, minor climatic fluctuations have been occurring, which are recorded in the landscape and sedimentary deposits. A good example is the extant Paraguay River course, which has resulted from a major avulsion during the mid-Holocene that caused the Nabileque paleomeander belt to be abandoned.

The Pantanal is a place of changing rivers and public policies must consider this dynamism. To achieve the sustainable development, including conservation policies, it is necessary to understand the natural systems of the Pantanal, its basin origin and evolution, neotectonics and associated subsiding fault blocks, and hydrosedimentological dynamics. In an ever-changing landscape like the Pantanal, the knowledge about the geological history of the region and about the functioning of the several active geological systems can significantly contribute to the rational occupation and preservation of the greatest world tropical wetland.

Acknowledgments The authors thank the São Paulo Research Foundation (FAPESP) (2014/ 06889-2) for financial support to our research in the Pantanal Basin, the National Council for Scientific and Technological Development (CNPq) for grants to MLA (308563/2013-1), and Filipe Giovanini Varejão and Michele Andriolli Custódio for their assistance in the preparation of figures.

\section{References}

1. Ussami N, Shiraiwa S, Dominguez JML (1999) Basement reactivation in a sub-Andean foreland flexural bulge: the Pantanal wetland, SW Brazil. Tectonics 18(1):25-39

2. Padovani CR (2010) Dinâmica das Inundações do Pantanal. Universidade de São Paulo/ESALQ, Piracicaba

3. Junk WJ, Brown M, Campbell IC, Finlayson M, Gopal B, Ramberg L, Warner BG (2006) The comparative biodiversity of seven globally important wetlands: a synthesis. Aquat Sci 68: 400-414

4. Junk WJ, Cunha CN, Wantzen KM, Petermann P, Strüssmann C, Marques MI, Adis J (2006) Biodiversity and its conservation in the Pantanal of Mato Grosso, Brazil. Aquat Sci 68: 279-309 
5. Assine ML, Macedo HA, Stevaux JC, Bergier I, Padovani C, Silva A (2015) Avulsive rivers in the hydrology of the pantanal wetland. Hdb Environ Chem. doi:10.1007/698_2015_351

6. Assine ML (2003) Sedimentação na Bacia do Pantanal Mato-Grossense, Centro-Oeste do Brasil. Tese de Livre-Docência, Universidade Estadual Paulista - Unesp, Rio Claro

7. Warren LV, Quaglio F, Simões MG, Freitas BT, Assine ML, Ricommini C (2014) Underneath the pantanal wetland: a deep-time history of Gondwana assembly, climate change, and the dawn of metazoan life. Hdb Environ Chem. doi:10.1007/698_2014_326

8. Assine ML, Soares PC, Milani EJ (1994) Sequiências tectono-sedimentares mesopaleozóicas da Bacia do Paraná, Sul do Brasil. Revista Brasileira de Geociências 24(2):77-89

9. Assine ML, Perinotto JAJ, Alvarenga CJS, Petri S (1998) Arquitetura estratigráfica, tratos deposicionais e paleogeografia da Bacia do Paraná (Brasil) no Neo-Ordoviciano/Eo-Siluriano. Revista Brasileira de Geociências 28:61-76

10. Cogné N, Gallagher K, Cobbold PR, Riccomini C, Gautheron C (2012) Post-breakup tectonics in southeast Brazil from thermochronological data and combined inverse-forward thermal history modeling. J Geophys Res Solid Earth 117(B11), B11413

11. King LC (1956) A geomorfologia do Brasil Oriental. Revista Brasileira de Geografia 18(147-265):147-265

12. Ladeira FSB (2014) Gondwana Paleosurfaces in the State of Rio Grande do Sul, Southern Brazil. In: Rabassa J, Ollier C (eds) Gondwana landscapes in southern South America. Springer, Dordrecht, pp 135-159

13. Valadão RC (2009) Geodinâmica de superfícies de aplanamento, desnudação continental e tectônica ativa como condicionantes da megageomorfologia do Brasil oriental. Revista Brasileira Geomorfologia 10(2):77-90

14. Martonne E (1943) Problemas morfológicos do Brasil tropical atlântico. Revista Brasileira de Geografia 1(4):523-550

15. Almeida FFM (1958) O Planalto Paulistano. In: Azevedo A (ed) A cidade de São Paulo, vol v. 1 (A Região de São Paulo). Associação dos Geógrafos Brasileiros, São Paulo, pp 113-167

16. Ab'Sáber AN, Bigarella JJ (1961) Superfícies aplainadas do primeiro planalto do Paraná. Boletim Paranaense de Geografia 4(5):116-125

17. Retallack GJ (2010) Lateritization and bauxitization events. Econ Geol 105(3):655-667

18. Spier CA, Vasconcelos PM, Oliviera SM (2006) 40 Ar/39 Ar geochronological constraints on the evolution of lateritic iron deposits in the Quadrilátero Ferrífero, Minas Gerais, Brazil. Chem Geol 234(1):79-104

19. Zachos JC, Shackleton NJ, Revenaugh JS, Pälike H, Flower BP (2001) Climate response to orbital forcing across the Oligocene-Miocene boundary. Science 292(5515):274-278

20. Riccomini C, Sant'Anna LG, Ferrari AL (2004) Evolução geológica do rift continental do sudeste do Brasil. In: Mantesso-Neto V, Bartorelli A, Carneiro CDR, Brito-Neves BB (eds) Geologia do continente Sul-Americano: evolução da obra de Fernando Flávio Marques de Almeida. Beca São Paulo, pp 383-405

21. Gallagher K, Hawkesworth C, Mantovani M (1995) Denudation, fission track analysis and the long-term evolution of passive margin topography: application to the southeast Brazilian margin. J South Am Earth Sci 8(1):65-77

22. Hiruma ST, Riccomini C, Modenesi-Gauttieri MC, Hackspacher PC, Neto JCH, FrancoMagalhães AOB (2010) Denudation history of the Bocaina Plateau, Serra do Mar, southeastern Brazil: relationships to Gondwana breakup and passive margin development. Gondwana Res 18(4):674-687

23. Grohmann CH, Riccomini C (2012) Análise digital de terreno e evolução de longo-termo de relevo do centro-leste brasileiro. Geologia USP Série Científica 12(2):129-150

24. CPRM (2004) Mapa geológico e de recursos minerais do Estado de Mato Grosso. CPRM Serviço Geológico do Brasil, Scale 1:1,000,000. Rio de Janeiro

25. CPRM (2006) Mapa geológico e de recursos minerais do Estado de Mato Grosso do Sul. CPRM - Serviço Geológico do Brasil, Scale 1:1,000,000. Rio de Janeiro 
26. Ross JLS, Santos LM (1982) Geomorfologia. In: Brasil (ed) Ministério das Minas e Energia. Secretaria Geral. Projeto RADAMBRASIL. Folha SD.21 Cuiabá, vol (Levantamento de Recursos Naturais, 26). MME/SG/RADAMBRASIL, Rio de Janeiro, pp 193-256

27. Ab'Sáber AN (1988) O Pantanal Mato-Grossense e a teoria dos refúgios. Revista Brasileira de Geografia 50:9-57

28. Almeida FFM (1964) Geologia do centro-oeste mato-grossense. Boletim da Divisão de Geologia e Mineralogia 215:1-133

29. Braucher R, Bourles D, Colin F, Brown E, Boulange B (1998) Brazilian laterite dynamics using in situ-produced 10 Be. Earth Planet Sci Lett 163(1):197-205

30. Pupim FN, Bierman PR, Assine ML, Rood DH, Silva A, Merino ER (2015) Erosion rates and landscape evolution of the lowlands of the Upper Paraguay River basin (Brazil) from cosmogenic 10Be. Geomorphology 234:151-160

31. Catto AJ (1975) Análise geológica e geofísica da Bacia do Pantanal Matogrossense. Rio de Janeiro, Petrobrás, DEPEX/SEDOT report 5296, 23 pp

32. Hackspacher P, Ribeiro L, Ribeiro M, Fetter A, Neto JH, Tello C, Dantas E (2004) Consolidation and break-up of the South American platform in southeastern Brazil: tectonothermal and denudation histories. Gondwana Res 7(1):91-101

33. Ramos VA (2010) The tectonic regime along the Andes: Present day and Mesozoic regimes. Geol J 45(1):2-25

34. Melo MS, Riccomini C, Hasui Y, Almeida FFM, Coimbra AM (1985) Geologia e evolução do sistema de bacias tafrogênicas continentais do sudeste do Brasil. Revista Brasileira de Geociências 15:193-201

35. Almeida FFM, Carneiro CDR (1998) Origem e evolução da Serra do Mar. Revista Brasileira de Geociências 28(2):135-150

36. Almeida FFM (1959) Traços gerais da geomorfologia do Centro-Oeste brasileiro. In: Almeida FFM, Lima MA (eds) Planalto Centro-Ocidental e Pantanal Matogrossense, vol Guia de Excursão $\mathrm{n}^{\circ} 1$ do XVIII Congresso Internacional de Geografia. Conselho Nacional de Geografia, Rio de Janeiro, pp 7-65

37. Shiraiwa S (1994) Flexura da litosfera continental sob os Andes Centrais e a origem da Bacia do Pantanal. Tese de Doutoramento, Universidade de São Paulo, São Paulo

38. Horton BK, DeCelles PG (1997) The modern foreland basin system adjacent to the Central Andes. Geology 25(10):895-898

39. Feng M, van der Lee S, Assumpção M (2007) Upper mantle structure of South America from joint inversion of waveforms and fundamental mode group velocities of Rayleigh waves. J Geophys Res 112(B4), B04312

40. Weyler G (1962) Projeto Pantanal: relatório final dos poços perfurados no Pantanal Matogrossense. Petrobrás/DEBSP, Ponta Grossa

41. Weyler G (1964) Projeto Pantanal. Relatorio Final de abandono dos poços SBst-1A-MT (São Bento), FPst-1-MT (Faz. Piquiri) e LCst-1A-MT (Lagoa do Cascavel). Petrobras/DEBSP, Ponta Grossa

42. Almeida FFM (1945) Geologia do Sudoeste Mato-grossense. Boletim da Divisão de Geologia e Mineralogia 116:19-25

43. Hamilton SK, Sippel SJ, Melack JM (1996) Inundation patterns in the Pantanal wetland of South America determined from passive microwave remote sensing. Archiv für Hydrobiologie 137(1):1-23

44. Silva JSV, Abdon MM (1998) Delimitação do Pantanal brasileiro e suas sub-regiões. EMBRAPA 33 (Especial) 1703-1711

45. Assine ML, Merino ER, Pupim FN, Macedo HA, Santos MGM (2015) The Quaternary alluvial systems tract of the Brazilian Pantanal Basin. Braz J Geol, submitted

46. McGlue MM, Silva A, Corradini FA, Zani H, Trees MA, Ellis GS, Parolin M, Swarzenski PW, Cohen AS, Assine ML (2011) Limnogeology in Brazil's "forgotten wilderness": a synthesis from the large floodplain lakes of the Pantanal. J Paleolimnol 46(2):273-289 
47. McGlue MM, Silva A, Assine ML, Stevaux JC, Cruz FW (2015) Paleolimnology in the pantanal: using lake sediments to track quaternary environmental change in the world's largest tropical wetland. Hdb Environ Chem. doi:10.1007/698_2015_350

48. Macedo HA, Assine ML, Pupim FN, Merino ER, Stevaux JC, Silva A (2014) Mudanças paleohidrológicas na planície do rio Paraguai, Quaternario do Pantanal. Revista Brasileira Geomorfologia 15:75-85

49. Kuerten S, Assine ML (2011) O rio Paraguai no megaleque do Nabileque, sudoeste do Pantanal Mato-Grossense, MS. Revista Brasileira de Geociências 41(4):642-653

50. Braun EWG (1977) Cone aluvial do Taquari, unidade geomórfica marcante da planície quaternária do Pantanal. Revista Brasileira Geografia 39(4):164-180

51. Assine ML (2005) River avulsions on the Taquari megafan, Pantanal wetland, Brazil. Geomorphology 70(3-4):357-371

52. Corradini FA, Assine ML (2012) Compartimentação geomorfológica e processos deposicionais no megaleque fluvial do rio São Lourenço, Pantanal mato-grossense. Revista Brasileira de Geociências 42:20-33

53. Assine ML, Corradini FA, Pupim FN, McGlue MM (2014) Channel arrangements and depositional styles in the São Lourenço fluvial megafan, Brazilian Pantanal wetland. Sediment Geol 301:172-184

54. Facincani EM, Assine ML (2010) Geomorfologia fluvial do rio Aquidauana, borda sudeste do Pantanal Mato-Grossense. In: Martins Junior C, Oliveira Neto AF (eds) Revelando Aquidauana. Serie Fronteiras n ${ }^{\circ}$. Editora da UFMS, Campo Grande, pp 267-284

55. Zani H, Assine ML, McGlue MM (2012) Remote sensing analysis of depositional landforms in alluvial settings: Method development and application to the Taquari megafan, Pantanal (Brazil). Geomorphology 161-162:82-92

56. Pupim FN (2014) Geomorfologia e paleo-hidrologia dos megaleques dos rios Cuiabá e São Lourenço, Quaternário da Bacia do Pantanal. Universidade Estadual Paulista - Unesp, Rio Claro

57. Assine ML, Soares PC (2004) Quaternary of the Pantanal, west-central Brazil. Quat Int 114(1): $23-34$

58. Tricart J (1982) El Pantanal: un ejemplo del impacto geomorfologico sobre el ambiente. Informaciones Geograficas (Chile) 29:81-97

59. Klammer G (1982) Die Paläovüste des Pantanal von Mato Grosso und die pleistozäne Klimageschichte der brasilianischen Randtropen. Zeitschrift für Geomorphologie 26(4): 393-416

60. Clapperton C (1993) Quaternary Geology and Geomorphology of South America. Elsevier, Amsterdam

61. May JH, Zech R, Veit H (2008) Late Quaternary paleosol-sediment-sequences and landscape evolution along the Andean piedmont, Bolivian Chaco. Geomorphology 98:34-54

62. Latrubesse EM, Stevaux JC, Cremon EH, May J-H, Tatumi SH, Hurtado MA, Bezada M, Argollo JB (2012) Late Quaternary megafans, fans and fluvio-aeolian interactions in the Bolivian Chaco, Tropical South America. Palaeogeogr Palaeoclimatol Palaeoecol 356-357: 75-88

63. Whitney BS, Mayle FE, Punyasena SW, Fitzpatrick KA, Burn MJ, Guillen R, Chavez E, Mann D, Pennington RT, Metcalfe SE (2011) A 45kyr palaeoclimate record from the lowland interior of tropical South America. Palaeogeogr Palaeoclimatol Palaeoecol 307(1-4):177-192

64. McGlue MM, Silva A, Zani H, Corradini FA, Parolin M, Abel EJ, Cohen AS, Assine ML, Ellis GS, Trees MA, Kuerten S, Gradella FS, Rasbold GG (2012) Lacustrine records of Holocene flood pulse dynamics in the Upper Paraguay River watershed (Pantanal wetlands, Brazil). Quat Res 78(2):285-294

65. Zani H, Assine ML (2011) Paleocanais no megaleque do rio Taquari: mapeamento e significado geomorfológico. Revista Brasileira de Geociências 41:37-45 
66. Chiessi CM, Mulitza S, Pätzold J, Wefer G (2010) How different proxies record precipitation variability over southeastern South America. Earth and Environmental Science IOP Conference Series, vol 9, 012007

67. Por FD (1995) The Pantanal of Mato Grosso (Brazil) - World's Largest Wetlands. Kluwer Academic, Dordrecht

68. Bezerra MAO (1999) O Uso de Multi-traçadores na Reconstrução do Holoceno no Pantanal Mato-grossense, Corumbá, MS. Tese de Doutorado, Universidade Federal de São Carlos, São Carlos

69. Bezerra MAO, Mozeto AA (2008) Deposição de carbono orgânico na planície de inundação do Rio Paraguai durante o Holoceno médio. Oecologia Bras 12:155-171

70. Pott A, Silva JSV (2015) Terrestrial and aquatic vegetation diversity of the pantanal wetland. Hdb Environ Chem. doi:10.1007/698_2015_352

71. Kuerten S, Parolin M, Assine ML, McGlue MM (2013) Sponge spicules indicate Holocene environmental changes on the Nabileque River floodplain, southern Pantanal, Brazil. J Paleolimnol 49(2):171-183

72. Merino ER, Assine ML, Pupim FDN (2013) Estilos fluviais e evidências de mudanças ambientais na planície do rio Miranda, Pantanal. Revista Brasileira Geomorfologia 14(2): $127-134$

73. Cunha J (1943) Cobre de Jaurú e lagoas alcalinas do Pantanal (Mato Grosso). Boletim DNPM/ LPM 6:1-53

74. Evans TL, Costa M (2013) Landcover classification of the Lower Nhecolândia subregion of the Brazilian Pantanal Wetlands using ALOS/PALSAR, RADARSAT-2 and ENVISAT/ ASAR imagery. Remote Sens Environ 128:118-137

75. Valverde O (1972) Fundamentos geográficos do planejamento do Município de Corumbá. Revista Brasileira de Geografia 34:49-144

76. Wilhelmy H (1958) Umlaufseen and dammuferseen tropischer tiefland flüsse. Zeitschrift fur Geomorphologie NF 2:27-54

77. Goudie AS (1991) Pans. Prog Phys Geogr 15(3):221-237

78. Goudie AS, Wells GL (1995) The nature, distribution and formation of pans in arid zones. Earth Sci Rev 38(1):1-69

79. Colinvaux PA, Oliveira PE, Bush MB (2000) Amazonian and neotropical plant communities on glacial time-scales: the failure of the aridity and refuge hypotheses. Quat Sci Rev 19: 141-169

80. Soares AP, Soares PC, Assine ML (2003) Areiais e lagoas do Pantanal, Brasil: herança paleoclimática? Revista Brasileira de Geociências 33:211-224

81. Almeida TIR, Calijuri MC, Falco PB, Casali SP, Kupriyanova E, Paranhos Filho AC, Sigolo JB, Bertolo RA (2011) Biogeochemical processes and the diversity of Nhecolândia lakes, Brazil. Anais da Academia Brasileira de Ciências 83:391-407

82. Barbiéro L, Queiróz-Neto JP, Ciornei G, Sakamoto AY, Cappelari B, Fernandes E, Valles V (2002) Geochemistry of water and groundwater in the Nhecolândia, Pantanal of Mato Grosso, Brazil: variability and associated process. Wetlands 22(3):528-540

83. Furquim SAC, Graham RC, Barbiero L, Queiroz Neto JP, Vidal-Torrado P (2010) Soil mineral genesis and distribution in a saline lake landscape of the Pantanal Wetland, Brazil. Geoderma 154(3-4):518-528

84. Furian S, Martins ERC, Parizotto TM, Rezende-Filho AT, Victoria RL, Barbiero L (2013) Chemical diversity and spatial variability in myriad lakes in Nhecolândia in the Pantanal wetlands of Brazil. Limnol Oceanogr 58(6):2249-2261

85. Bergier I, Krusche A, Guérin F (2014) Alkaline lakes dynamics in the Nhecolândia landscape. Hdb Environ Chem. doi:10.1007/698_2014_327

86. Soares PC, Assine ML, Rabelo L The Pantanal Basin: recent tectonics, relationships to the Transbrasiliano Lineament. In: 9th Simpósio Brasileiro de Sensoriamento Remoto, Santos, 1998. INPE - São José dos Campos, pp 459-469 
87. Paranhos Filho AC, Nummer AR, Albrez EA, Ribeiro AA, Machado R (2013) A study of structural lineaments in Pantanal (Brazil) using remote sensing data. Ann Braz Acad Sci 85(3):913-922

88. Ussami N, Padilha AL, Fisseha S, Porsani JL, Souza LAP, Boggiani PC, Carvalho MJ (2000) Investigações geofísicas integradas na planície do Pantanal Mato-Grossense: implicações tectônicas e hidrogeológicas de sub-superfície. $3^{\circ}$ Simpósio sobre Recursos Naturais e Sócio-Econômicos do Pantanal, Corumbá, Resumos, p 125

89. Dias F, Assumpção M, Facincani EM, França GS, Assine ML, Paranhos Filho AC, Gamarra RM. The 2009 earthquake, magnitude $4.8 \mathrm{mb}$, in the Pantanal Wetlands, westcentral Brazil, Anais da Academia Brasileira de Ciências, submitted

90. Assumpção M, Sacek V (2013) Intra-plate seismicity and flexural stresses in central Brazil. Geophys Res Lett 40(3):487-491

91. Assine ML, Silva A (2009) Contrasting fluvial styles of the Paraguay River in the northwestern border of the Pantanal wetland, Brazil. Geomorphology 113(3-4):189-199

92. May JH, Veit H (2009) Late quaternary paleosols and their paleoenvironmental significance along the Andean piedmont, Eastern Bolivia. Geomorphology 100-116 